This PDF is a simplified version of the original article published in Internet Archaeology. Enlarged images which support this publication can be found in the original version online. All links also go to the online version.

\title{
Current State of Archiving Archaeological Reports in Bulgaria: still more physical than digital
}

\author{
Nadezhda Kecheva
}

This article provides an overview of the current state of archaeological archiving in Bulgaria. It briefly outlines the legislation that regulates archaeological fieldwork activities. Although the national legislation regulates the non-destructive and destructive activities equally, differences occur owing to the existence of the 'Archaeological Map of Bulgaria', a national 'sites and monuments' type of archaeological information system. Currently, online storage of brief data and information is possible for different archaeological sites. Its next version will be based on GIS and geographic features that allow storage of raw field survey data. According to the regulations, paper/digital reports of all fieldwork activities are collected yearly and copies of all of them are stored at the 'Scientific Archive' section at the National Archaeological Institute with Museum at the Bulgarian Academy of Sciences. Although their digitisation is still in the early stages, the good news is that the centralised archaeological workflow regulates their storage in one place, which makes them more easily accessible. The annual publication of the 'Archaeological Discoveries and Excavations' series, with summaries for all fieldwork activities in the year, is also very useful for keeping track of the archaeological work and results.

\section{Introduction}

In an era of rapid developments in technology, archaeological digital archiving in Bulgaria still has a long way to go to be fully achieved. Its direction and state of development depend on deliberate policies led by the Bulgarian Ministry of Culture and National Archaeological Institute with Museum at the Bulgarian Academy of Sciences (NAIM-BAS) since the centralised organisation of Bulgarian archaeology relies on decisions made in these two national institutions. They are responsible for the organisation of the workflow of: 
- digitisation of old physical reports collected in the 20th century

- developing standards for raw data collection

- creating and maintaining an online system for collecting data and reports

According to the national legislation guidelines, reporting and archiving for both nondestructive (including all types of projects where fieldwork is conducted) and destructive fieldwork activities are the same. Differences in the state of digitisation occur owing to the existence of a national 'sites and monuments' archaeological information system created for recording results from non-destructive activities. Field survey recording is one step ahead in digitisation. From 2022, it will be possible to upload collections of standardised raw data (created since 2011) into an online archaeological geographic information system 'Archaeological Map of Bulgaria' (GIS AKB).

This article represents the author's point of view as an archaeologist in NAIM-BAS. The author has first-person knowledge and has actively participated in the digitisation of the paper records of archaeological sites into the 'Archaeological Map of Bulgaria' and acts as an observer of the 'Scientific Archive' paper reports digitisation.

\section{Brief Historical Review of Fieldwork and Archiving in Bulgarian Archaeology}

Since the middle of the 20th century, archaeological fieldwork activities in Bulgaria were recorded and archived on paper. Systematic archaeological fieldwork activities in the second half of the 20th century were controlled by NAIM-BAS. Its section named 'Scientific Archive' has been part of the 'Scientific Archive' of the Bulgarian Academy of Sciences since 1959. Since 1973, it has included a specialised archive, which is a collection of legally regulated documents on paper, created as a result of annual archaeological fieldwork activities within Bulgaria. Up until the beginning of the 21st century the 'Law for Cultural Monuments and Museums', created in 1969 and modified regularly up to 2006, has regulated cultural heritage in Bulgaria (Закон за паметниците на културата и музеите (обн. ДВ. бр. 29 от 11 април 1969 г., изм. в периода 1973-2006г., отм. ДВ. бр. 19 от 13 март 2009 г.) 2021). Since 1996-1997 a regulation for fieldwork activities (Правилник за провеждане на теренни археологически проучвания в Република България (обн. ДВ. бр. 12 от 7 февруари 1997 г., отменен) 2021) and a Decree for 'Archaeological Map of Bulgaria' (Наредба № 26 от 10 април 1996 г. за развитието, ползването и управлението на автоматизираната информационна система 'Археологическа карта на България' (обн. ДВ. бр. 34 от 23 април 1996 г., отм. ДВ. бр. 32 от 19 април 2011 г.) 2021) managed the workflow of archaeological activities. Scientific report guidelines were fully described in the regulation for fieldwork activities. 


\section{Organisation of Fieldwork Activities and Archiving in Bulgarian Archaeology: Current Practice}

The state of the organisation of fieldwork activities and archiving in archaeology in Bulgaria is described in national regulations. New Bulgarian legislation for cultural heritage was issued by the Ministry of Culture in 2009 and 2011. This regulates more clearly archaeological fieldwork activities through:

- Cultural Heritage Act (Закон за културното наследство (в сила от 10.04.2009 г., посл. изм. ДВ. бр. 17 от 26 фревруари 2021 г.) 2021)

- Decree for regulation of archaeological fieldwork activities (Наредба № Н-00-0001 от 14 февруари 2011 г. за извършване на теренни археологически проучвания (в сила от 01.03.2011 г., посл. доп. ДВ. бр. 49 от 11 юни 2021 г.) 2021)

- Decree for regulation of archaeological information system 'Archaeological Map of Bulgaria' (Наредба № H-2 от 6 април 2011 г. за създаване, поддържане и предоставяне на информацията от автоматизирана информационна система 'Археологическа карта на България' (в сила от 19.04.2011 г.) 2021)

The most recent Bulgarian legislation still includes a clear workflow with a centralised structure controlling the quality of all legal archaeological fieldwork activities, permissions, data gathering, and archiving. Permissions for conducting all kinds of archaeological fieldwork activities are individual, and they are given to archaeologists working in cultural institutions for a calendar year by the minister of culture for scientific projects and by the chairman of the 'Council of Fieldwork Activities' (who is the director of NAIM-BAS) for rescue fieldwork activities (both non-destructive surveys and excavations). Written and oral reports of all archaeological fieldwork activities in Bulgaria are given to NAIM-BAS and the Bulgarian Ministry of Culture, covering a calendar year and per permission. These reports take the form of a conference in February and March of the following year. Specialists from NAIM-BAS in the field of archaeology are part of a committee responsible for checking the quality of both written and oral reports. After positive feedback from the committee, the archaeologists are able to re-apply for permissions for the next calendar year.

The main task of the 'Scientific Archive' of NAIM-BAS is receiving, registering, storing, and preserving scientific archaeological fieldwork reports submitted annually. The reports for non-destructive and destructive activities follow the same guidelines and the minimum set of documents they should contain is:

- Scientific summary

- Field diary

- Graphic documentation

- Photographic documentation

- Field inventory book

- Registration card(s) for the 'Archaeological Map of Bulgaria' information system

- Scientific summary with graphic and photographic documentation for publication in the 'Archaeological Discoveries and Excavations' series published each year 
The reports are collected once a year in one physical copy and, since 2015, two additional digital copies (on CD/DVD). The physical copy and one of the digital copies are stored in the 'Scientific Archive' of NAIM-BAS. The other digital copy is preserved in the National Institute of Immovable Cultural Heritage, part of the Ministry of Culture. Another physical and/or digital copy is supplied to the local regional museum in the corresponding administrative unit of Bulgaria. The digital copy can contain the minimum set of mandatory documents as a single PDF or as multiple files.

Access to these reports is also regulated by the national legislation. For a period of 10 years following the deposition of the reports, they can be used only with the permission of the scientific supervisors of the corresponding archaeological fieldwork activities. The same rules apply for both the first scientific publication and postprocessing and analysis of artefacts. Once the 10-year period elapses, the reports can be used by following the NAIM-BAS regulations for access.

\subsection{Reports from non-destructive fieldwork activities - field and geophysical surveys}

Apart from the above-mentioned minimum set of mandatory documents handed in on paper and two digital copies, data and information for activities on archaeological sites are stored in the archaeological information system 'Archaeological Map of Bulgaria'. The geographic version of the system can handle raw field data in different data formats collected during the investigation (Kecheva 2019). The raw data may include attributes with additional information. This is part of the digital archive of the report filled in by the archaeologists themselves. The system is available online (http://www.naim-bas.com/akb/), with limited and registered access according to the national legislation. Its creation, development and maintenance are carried out by NAIM-BAS. Regional administrators at lower levels and national administrators at higher levels are responsible for checking the quality of the users' input data. The national administrators, both scientists from NAIM-BAS, give access to the system to archaeologists working in cultural institutions.

During the duration of the ARIADNE project (2013-2017), more than 13,000 old physical copies of recorded sites created in the period 1992-1996 were scanned (Кечева in press). Geographic coordinates of the sites were estimated in GIS using available descriptions of azimuth and distance, as well as maps printed on the old physical copies. The estimated geographic coordinates were verified by old topographic maps in different scales, orthophotos, and satellite imagery. Additional notes and the name of the person who placed the coordinates were added. These data were entered in a standard Microsoft Excel spreadsheet available for each record in GIS AKB. The scanned physical copies will also be available in GIS AKB as a digital archive in attached files for each registration card for a site. 


\subsection{Reports from destructive fieldwork activities}

Reports for both excavation and monitoring fieldwork activities also follow the above guidelines for the minimum set of mandatory documents in physical copy. The digital copies (CDs/DVDs) make it possible to include raw data in different formats. Since this is optional, it is not clear how many archaeologists add this additional information.

\section{Future Perspectives - From Physical to Digital}

In 2015, a project financed only by NAIM-BAS was set up for the digitisation of physical copies of the archaeological reports stored at the 'Scientific Archive'. Microsoft Excel and Microsoft Access databases were created for collecting metadata information, and the physical copies were scanned starting from the oldest ones stored in the archive. It is still an ongoing process that is limited by both human and financial resources.

The long-term plan for a digital archive includes:

- Continuation of metadata digitisation for physical and digital copies

- Continuation of scanning of physical copies

- Online (on a server or a cloud) collection of the data currently stored on CDs/DVDs

- Creation of standards for collecting raw excavation data in digital format

- Creation and maintenance of the online system with registered access for the metadata, scanned documents, and raw data for both non-destructive and destructive fieldwork activities; GIS AKB could serve as this online system after additional development and modification.

\section{Conclusion}

This article has summarised the current state of progress of digitisation of the paper records relating to archaeological sites available in the 'Archaeological Map of Bulgaria' information system and the reports stored at the 'Scientific Archive' of NAIM-BAS. While the first has finished, the second one is still on-going. It is a large amount of work that requires more human and financial resources which are not available at present. The direction that NAIM-BAS has taken and still follows is the right one, but a greater focus on the FAIR principles and additional standards is 
necessary. The fact that all of the reports are stored in one place, i.e. the 'Scientific Archive' section at NAIM-BAS, significantly facilitates the work.

\section{Acknowledgements}

I would like to thank Ms Katrina Koleva, a senior expert at the Ministry of Culture and a former expert in the 'Scientific Archive' section at NAIM-BAS, for sharing information about the digitisation process of the paper reports stored there.

\section{Bibliography}

Закон за културното наследство (в сила от 10.04.2009 г., посл. изм. ДВ. бр. 17 от 26 февруари 2021 г.) 2021 https://www.lex.bg/laws/ldoc/2135623662 Accessed: 12 август 2021.

Закон за паметниците на културата и музеите (обн. ДВ. бр. 29 от 11 април 1969 г., изм. в периода 1973-2006г., отм. ДВ. бр. 19 от 13 март 2009 г.), 2021. http://www.museum-system.com/zakon-za-pametnicite-na-kulturata-imuzeite.html [Last accessed: 12 August 2021].

Кечева, Н.И. in press Археологическа карта на България - недеструктивни методи за теренни археологически проучвания и приложение на географски информационни системи. Дисертации.

Наредба № 26 от 10 април 1996 г. за развитието, ползването и управлението на автоматизираната информационна система 'Археологическа карта на България' (обн. ДВ. бр. 34 от 23 април 1996 г., отм. ДВ. бр. 32 от 19 април 2011 г.) 2021 https://www.lex.bg/bg/laws/ldoc/2135726963 [Last accessed: 12 August 2021].

Наредба № Н-00-0001 от 14 февруари 2011 г. за извършване на теренни археологически проучвания (в сила от 01.03.2011 г., посл. доп. ДВ. бр. 49 от 11 юни 2021 г.) 2021 https://www.lex.bg/laws/ldoc/2135720867 [Last accessed: 12 August 2021].

Наредба № H-2 от 6 април 2011 г. за създаване, поддържане и предоставяне на информацията от автоматизирана информационна система "Археологическа карта на България" (в сила от 19.04.2011 г.) 2021 https://www.lex.bg/laws/ldoc/2135726967 [Last accessed: 12 August 2021].

Правилник за провеждане на теренни археологически проучвания в Република България (обн. ДВ. бр. 12 от 7 февруари 1997 г., отменен)

2021 https://www.lex.bg/laws/ldoc/-13362650 [Last accessed: 12 August 2021]. 
Kecheva, N. 2019 'Archaeological map of Bulgaria - transport and pipeline infrastructure projects', Internet Archaeology 51. https://doi.org/10.11141/ia.51.2 